\title{
The Family Doctor and Nurse: The Dynamic Duo of Cuban Healthcare
}

\author{
Kelley H. Pattison ${ }^{1}$ \\ ${ }^{1}$ Bronson School of Nursing, Western Michigan University, Kalamazoo, Michigan, USA \\ Correspondence: Sam Abraham, Associate Professor of Nursing, 1001 Bethel Circle, Bethel College School of \\ Nursing, Mishawaka, Indiana, 46545, USA.
}

Received: January 29, 2018

Accepted: February 13, $2018 \quad$ Online Published: February 24, 2018

doi:10.20849/ijsn.v3i1.313

URL: https://doi.org/10.20849/ijsn.v3i1.313

\begin{abstract}
Following the Revolution of 1959, Fidel Castro declared healthcare a right for all Cuban citizens. In 1983 a pilot project was established which paired a family doctor and nurse to care for all persons within a neighborhood. The success of this project led to the establishment of the family doctor-nurse partnership to care for all Cuban citizens. Working together, the pair provided direct care, health assessment, risk management, and health promotion for a specified neighborhood. This novel way of providing primary care provides each Cuban with a family doctor and nurse. This arrangement has helped change the health of a nation.
\end{abstract}

Keywords: Cuban healthcare; family medicine in Cuba; Cuban public health

\section{Introduction}

Following the revolution of 1959, Fidel Castro established a nationwide public health service. Not only is health care in Cuba considered to be a basic human right, but it is also easily accessible, free for all citizens, and the responsibility of the government (De Vos, 2005; Pagliccia \& Perez, 2012). Caring for the citizens of the island nation is a daunting task which involves doctors, nurses, and community action groups such as the Federation of Cuban Women (FMC, Spanish acronym) and the Committee for the Defense of the Revolution (CDR). These community groups work with the family doctor and nurse to help organize immunization clinics, blood drives, and health promotion and prevention activities (Whiteford \& Branch, 2008).

The Cuban healthcare system is divided into three sectors. The first is the consultorio or neighborhood family doctor's office, the second is the polyclinic which provides support and referrals. Polyclinics are staffed with pediatricians, OB-GYNs, specialists and therapists (Gorry, 2013). The polyclinics are also responsible for keeping health statistics and reporting such to the Ministry of Public Health (MINSAP, Spanish acronym). The third link in the health care chain consisting of hospitals and specialty institutes. The family doctor-nurse care team delivers the care at the consultorio and their role will be the focus of this paper.

\section{Development of the Family Doctor-Nurse Partnership}

Cuban health officials determined family practice medicine was necessary to provide comprehensive health care. A pilot program was established in Havana in 1983 paring a family doctor and nurse in 15 neighborhood clinics (Keck \& Reed, 2012). Following the success of this pilot program, the Family Doctor-Nurse Program (Programa Medico y Enfermera de la Famila) was established in 1984, to bring health care to all Cuban people via this neighborhood based program. At this time, the Cuban people were dying from cardiovascular disease, diabetes, and cancer at an alarming rate (Perez, 2008). Castro's vision for this community-based family doctor-nurse program was that primary care would be provided at the community level with an emphasis on assessment, health promotion, and disease prevention by healthcare providers living and working in the same neighborhood as their patients. Thus, they would get to know the people they care for and experience the same problems and exposure to disease (Whiteford \& Branch, 2008). The Cuban people have restricted geographic mobility, which makes for a stable neighborhood population (Whiteford \& Branch, 2008).

\section{Objectives of the Family Doctor-Nurse Program}

The objectives of the Family Doctor-Nurse Program are as follows (Keck \& Reed, 2012):

$>$ Promote health through positive changes in the population's knowledge, sanitary habits, and lifestyle. 
$>$ Prevent the emergence of disease and damage to the population's health.

$>$ Guarantee early diagnosis, ambulatory services and hospitalization, as well as timely, continuous, and comprehensive medical care in the community.

$>$ Develop community-based rehabilitation for physically or psychologically disabled persons.

$>$ Achieve improvements in neighborhood environmental clean-up and in home hygiene.

$>$ Achieve improvements in social relations and integration of neighborhood residents and families

$>$ Develop studies that respond to the health needs of the population

\section{Roles and Responsibilities}

All Cuban physicians must work at a consultorio for one to two years after medical school graduation before they specialize in a field of medicine (Perez, 2008). During this time they are partnered with a nurse and together they care for the neighborhood assigned to them. For example, the doctor and nurse may both live in a large apartment block where their consultorio is also located (Warman, 2001). This may include as many as 150 families (Dresang et al., 2005). Here they will see patients in the consultorio Monday through Saturday from $8 \mathrm{am}-12 \mathrm{pm}$. In the afternoon they make home visits to check on patients who may need such care as blood pressure monitoring, vaccinations, dressing changes, or pre-and post- natal care. The doctor and nurse often split the home visits to see more patients in a day. Besides the care previously mentioned they also focus on health promotion and disease prevention at every visit. If a patient needs to be referred to the polyclinic for more specialized treatment, the doctor will usually accompany them. Since there are no electronic medical records this allows the family doctor to provide a seamless transition of care and also act as the patient advocate.

The nurse is seen as the lynchpin in this neighborhood based healthcare team. The physician may choose to leave after completing the required residency, but the nurse remains the constant feature in the neighborhood. It is not uncommon for the nurse to have lived in the neighborhood her entire life (Keck \& Reed, 2012). Beyond seeing patients in the office and at home visits the nurse also conducts an assessment of the physical condition, risk factors, and disease burden on every person in the neighborhood at least once per year.

\section{Continuous Assessment and Risk Evaluation}

Mandated by the Cuban government, Continuous Assessment and Risk Evaluation (CARE) is the process of an on ongoing analysis of the health and risk of disease of the Cuban people. This assessment informs the Health Ministry of the general health of the populous and what current disease burden they face, what risk factors need attention, and what rehabilitation services are needed (Keck \& Reed, 2012).

The assessments categorize individuals into four groups as seen in Table 1 (Campion \& Morrissey, 2013; Gorry, 2013). By doing this yearly assessment and categorizing people by this method, it allows the Ministry of Health to track healthcare needs and services. Importantly, it also allows the family doctor and the nurse a means to design treatment and follow-up plans.

Table 1. Categories of individuals in four groups

\begin{tabular}{|c|c|c|c|}
\hline Group & Assessment Category & Frequency & Examples \\
\hline Group 1 & Apparently healthy & Seen once per year & \\
\hline Group 2 & $\begin{array}{l}\text { At-risk and may develop health } \\
\text { problems due to risk exposure at } \\
\text { home or work }\end{array}$ & Seen twice a year & $\begin{array}{l}\text { Examples } \\
\text { smokers }\end{array}$ \\
\hline Group 3 & $\begin{array}{l}\text { Sick individuals, including those with } \\
\text { chronic, communicable or } \\
\text { non-communicable disease }\end{array}$ & Seen three times a year & $\begin{array}{l}\text { Examples are stable } \\
\text { chronic lung disease }\end{array}$ \\
\hline Group 4 & $\begin{array}{l}\text { Disabled or otherwise incapacitated } \\
\text { individuals suffering from disruption } \\
\text { of their motor, functional, sensory, or } \\
\text { mental capacities }\end{array}$ & Seen twice a year & \\
\hline
\end{tabular}

\section{A Day in the Life}

On a recent trip to Havana the author was able to observe the family doctor and nurse as they cared for patients in the consultorio and on home visits. On this day patients were seen for follow-up care for diabetes and 
hypertension and a newly pregnant woman was seen for her first of the required 13 pre-natal visits. The medical records were paper and handwritten, no use of electronic medical records. Each family has a chart with separate sections for each member of the family. Besides providing care and education on health promotion and risk factor prevention specific to the disease afflicting the patient, the nurse was also providing information and education regarding mosquito control and eradication because of the Zika virus outbreak.

The nurse also kept track of statistics which must be reported monthly to the local health officials at the polyclinic. Such items include the number of patients in each CARE category, the number of patients with chronic disease e.g. diabetes, hypertension, as well as immunization status, the number of pregnancies and required pre-natal care. These house calls are also used to assess compliance with medical regimen.

The consultorio was a very small 2-room office (waiting room and exam room) on the first floor of a twelve story apartment building which housed approximately 1000 people. The waiting room had a few chairs in poor repair and was lit by a single light bulb hanging from a wire in the ceiling. The exam room was outfitted with a very old exam table covered with a sheet, and without an electric motor to raise or lower the table. There was also a metal table with stainless steel canisters which held clean and dirty gauze. There was no medication kept at the consultorio, nor was there equipment one might expect such as a scale, thermometer, otoscope or ophthalmoscope.

During the afternoon home visit the nurse administered vaccinations and taught a patient how to use a glucometer. Interestingly the glucometer and test strips are made in Cuba and the insulin is imported from Denmark. These supplies were considered to be easily affordable. However, the nurse explained the syringes are imported from China and are expensive, and thus each patient is given only 2 per month.

\section{Conclusion}

Providing healthcare for a nation using this primary care model is novel and laudatory. The family doctor and nurse have few resources at their disposal and rely heavily on the power of prevention. Frequent assessment and health education helped to lead Cuba to become the first country to eradicate the transmission of HIV and Syphilis from mother to child (Friedrich, 2015). This program which provides a doctor and nurse for each person, along with the foundation of early and frequent intervention, risk reduction, and health education has been effective in providing care to Cuba's people.

\section{References}

Campion, E.W., \& Morrissey, S. (2013). A different model-Medical care in Cuba. New England Journal of Medicine, 386, 297-299. https://doi.org/10.1056/NEJMp1215226

De Vos, P. (2005). No one left abandoned: Cuba's National Health System since the 1959 revolution. $\begin{array}{lllll}\text { International Journal of Health } & \text { Services, } & 35(1), & \text { 189-207. }\end{array}$ https://doi.org/10.2190/M72R-DBKD-2XWV-HJWB

Dresang, L.T., Brebrick, L., Murray, D., Shallue, A., \& Sullivan-Vedder, L. (2005). Family Medicine in Cuba: Community-oriented primary care and complementary and alternative Medicine. Journal of the American Board of Family Medicine, 18(4), 297-303. https://doi.org/10.3122/jabfm.18.4.297

Friedrich, M.J. (2015). Cuba eliminates mother-to-child transmission of HIV and Syphilis. Journal of the American Medical Association, 314(7), 661. https://doi.org/10.1001/jama.2015.9661

Gorry, C. (2013). Primary care forward: Raising the profile of Cuba's nursing profession. MEDICC Review, 15(2), 5-9.

Keck, C.W., \& Reed, G.A. (2012). The curious case of Cuba. American Journal of Public Health, 102(8), 13-22. https://doi.org/10.2105/AJPH.2012.300822

Pagliccia, N., \& Perez, A.A. (2012). The Cuban experience in public health: Does political will have a role? International Journal of Health Services, 42(1), 77-94. https://doi.org/10.2190/HS.42.1.h

Perez, C. (2008). Caring for Them from Birth to Death: The Practice of Community-Based Cuban Medicine. Rowman \& Littlefield. Lantham, MD.

Warman, A. (2001). Living the revolution: Cuban health workers. Journal of Clinical Nursing, 10, 311-319. https://doi.org/10.1046/j.1365-2702.2001.00491.x

Whiteford, L.M., \& Branch, L.G. (2008). Primary Health Care in Cuba The Other Revolution. Rowman \& Littlefield. Lantham, MD. 


\section{Copyrights}

Copyright for this article is retained by the author(s), with first publication rights granted to the journal.

This is an open-access article distributed under the terms and conditions of the Creative Commons Attribution license (http://creativecommons.org/licenses/by/4.0/). 